\title{
Knowledge of Farmers about Production Technology of Sugarcane in Sri Ganganagar District of Rajasthan, India
}

\author{
Abhimanyu Godara', Vikas Kumar ${ }^{2 *}$, Ajit Kumar Ghoslya ${ }^{2}$ and Jitendra Kumar ${ }^{3}$ \\ ${ }^{I}$ Department of Extension Education, SKRAU, Bikaner, India \\ ${ }^{2}$ Department of Extension Education, SKNAU, Jobner, India \\ ${ }^{3}$ Department of Extension Education, MPUAT, Udaipur, India \\ *Corresponding author
}

\section{A B S T R A C T}

Sugarcane is becoming an important cash crop for farmers because there is a great potential for sugar production and byproducts of sugarcane in

Keywords

Sugarcane,

Knowledge,

Technology,

Cultivation

Article Info

Accepted:

04 March 2020

Available Online:

10 April 2020 domestic market. The present study was conducted in purposely selected Sri Ganganagar district of Rajasthan. There are total ten tehsils in Sri Ganganagar district of Rajasthan, out of which, two tehsils namely Sri Karanpur and Sri Ganganagar were selected on the basis of maximum area under cultivation of sugarcane. From the list so prepared, 10 respondents were selected randomly from each identified village. Thus, in all 120 farmers were included in the sample of the study. The study clearly showed that majority of respondents i.e. 67.50 per cent fell in medium level knowledge group whereas 15.00 per cent sugarcane growers were observed in the low level knowledge group and remaining 17.50 per cent respondents possessed high level of knowledge about recommended production technology of sugarcane.

\section{Introduction}

Sugarcane (Saccharum officinarum L.) belongs to the Graminae family and Saccharum genus. Saccharum genus mainly comprises five species in which three are cultivated and two are wild species. Origin of the sugarcane is New Guinea. Sugarcane is one of the oldest commercial crop viable in tropics and sub-tropics of the world. Sugarcane is a ratoonable crop which can raise 5-6 ratoons before next cultivation. Number of ratoons can vary with different climatic conditions and agronomic practices.

Sugarcane is becoming an important cash crop for farmers because there is a great potential for sugar production and byproducts 
of sugarcane in domestic market. Therefore, the expansion of sugarcane industry in India would greatly benefit the economy by foreign exchange saving, generation of employment and income, development of rural area and living standard of rural people. India is considered as homeland of sugarcane.

The productivity of cane which was 56 tonnes in 1950-51 has gone up to 74.4 tonnes per hectare in 2017-18. In Rajasthan, it occupies an area of 0.07 lakh hectares with a total production of 4.89 lakh tonnes resulting an average productivity of 69.9 tonnes/ha during 2016-17.

\section{Materials and Methods}

The present study was conducted in purposely selected Sri Ganganagar district of Rajasthan. There are total ten tehsils in Sri Ganganagar district of Rajasthan, out of which, two tehsils namely Sri Karanpur and Sri Ganganagar were selected on the basis of maximum area under cultivation of sugarcane.

Further, a comprehensive list of all the major sugarcane growing villages was prepared in consultation with the personnel of Revenue and Agriculture Department from the identified tehsils. Six villages from each selected tehsil were taken on the basis of maximum area under sugarcane cultivation.

Thus, total twelve villages were selected for the present investigation. For selection of respondents, comprehensive list of sugarcane growers was prepared with the help of village patwari and agriculture supervisor of respective villages.

From the list so prepared, 10 respondents were selected randomly from each identified village. Thus, in all 120 farmers were included in the sample of the study.
Knowledge level of farmers about production technology of sugarcane

Under this section, it was tried to find out the level of knowledge of farmers about recommended production technology of sugarcane. Knowledge as a body of understood information possessed by an individual is one of the important components of behavior and plays an important role in adoption of an innovation. Keeping this view in mind, the level of knowledge of farmers about recommended production technology of sugarcane was assessed. The results are presented in subsequent tables.

\section{Distribution of respondents according to their knowledge about recommended production technology of sugarcane}

To get an overview of the knowledge level, the respondents were grouped into (i) Low (<60.49), (ii) Medium (60.49 to 69.66) and (iii) High (>69.66) knowledge level on the basis of calculated mean and standard deviation of the obtained knowledge scores. The distribution of respondents in each category is given in Table 1 . The data in Table 1 shows that out of 120 respondents, majority of respondents 67.50 per cent fell in medium level knowledge group whereas 15.00 per cent sugarcane growers were observed in low level knowledge group and remaining 17.50 per cent respondents possessed high level of knowledge about recommended production technology of sugarcane.

\section{Aspect wise knowledge of respondents about recommended production technology of sugarcane}

To get a clear picture of knowledge possessed by sugarcane growers, aspect wise knowledge of sugarcane growers was worked out. 
Table.1 Distribution of respondents on the basis of level of knowledge about recommended production technology of sugarcane $n=120$

\begin{tabular}{|c|l|c|c|}
\hline S.No. & Knowledge categories & \multicolumn{2}{|c|}{ Total respondents } \\
\cline { 3 - 4 } & & F & \% \\
\hline 1. & Low $(<60.49)$ & 18 & 15.00 \\
\hline $\mathbf{2 .}$ & Medium $(60.49$ to 69.66) & 81 & 67.50 \\
\hline $\mathbf{3 .}$ & High $(>69.66)$ & 21 & 17.50 \\
\hline & Total & $\mathbf{1 2 0}$ & $\mathbf{1 0 0 . 0 0}$ \\
\hline
\end{tabular}

Mean $=65.08, \mathrm{SD}=4.59, \mathrm{~F}=$ Frequency, $\%=$ per cent

Table. 2 Extent of knowledge of farmers about recommended production technology of sugarcane $n=120$

\begin{tabular}{|c|l|c|c|}
\hline S. No. & Aspects/ Practices & \multicolumn{2}{|c|}{ Total respondents } \\
\cline { 3 - 4 } & & MPS & RANK \\
\hline 1. & Use of high yielding varieties & 63.51 & XI \\
\hline 2. & Soil and field preparation & 75.17 & VII \\
\hline 3. & Soil treatment & 78.33 & III \\
\hline 4. & Seed treatment & 75.28 & VI \\
\hline 5. & Time of sowing & 63.75 & X \\
\hline 6. & Seed rate \& recommended method of sowing & 77.64 & V \\
\hline 7. & Fertilizer application & 72.28 & VIII \\
\hline 8. & Irrigation management & 86.67 & I \\
\hline 9. & Weed management & 77.78 & IV \\
\hline 10. & Plant protection measures & 67.06 & IX \\
\hline 11. & Harvesting & 85.28 & II \\
\hline
\end{tabular}

For this mean per cent scores for each practice was calculated and ranks were accorded. The results of the same have been presented in Table 2.

In overall, it has found that first rank is given to irrigation management with MPS 86.67, followed by harvesting with MPS 85.28 , soil treatment with MPS 78.33, weed management with MPS 77.78 and were ranked second, third and fourth respectively. It indicate that sugarcane growers knew very well about harvesting, soil treatment and weed management. Whereas less knowledge regarding Plant protection measures with
MPS 67.06, Time of sowing with MPS 63.75 and Use of high yielding varieties with MPS 63.51 .

\section{References}

Ambavane, D. N. (2014). Knowledge and adoption of recommended chilli production technology by the growers. M. Sc. (Agri) Thesis, VNMKV, Parbhani (M.S.).

Chaudhari, P.C. and Sharma, R. (2011). Knowledge of chilli growers about various interventions of chilli cultivation under Institution Village 
Linkage Programmes. Indian Res. J. of Ext. Edu. 12(2): 25-28.

Patel, P.L., Supe, S.V. and Baber, M.S. (2013). Knowledge of sugarcane grower regarding integrated pest and disease management practices in Nandurbar district. International Journal of Plant Protection 6(1):210-212.

Rathod, G.V., Salame, S.P., and Deokate, N. (2018). Knowledge and adoption of improved cultivation practices by sugarcane growers. International Journal of Chemical Studies. 6(6): 653-
654.

Sasane, G. K., Khule, R.P., and Jagdale U.D. (2010). Knowledge and adoption of sugarcane management practices by the farmer. Agriculture Update, 5(3/4): 391-393.

Suganya, S., Kavaskar, M. and Jeya R. (2018). Study on knowledge level of Recommended cultivation practices of sugarcane growers in Tamil Nadu. International Journal of Agriculture Sciences, 10(14): 6739-6741.

\section{How to cite this article:}

Abhimanyu Godara, Vikas Kumar, Ajit Kumar Ghoslya and Jitendra Kumar. 2020. Knowledge of Farmers about Production Technology of Sugarcane in Sri Ganganagar District of Rajasthan, India. Int.J.Curr.Microbiol.App.Sci. 9(04): 245-248.

doi: https://doi.org/10.20546/ijcmas.2020.904.029 